\title{
Analysis of Bunch Quality in Oil Palm Hybrid Cross Combinations under Krishna-Godavari Zone of Andhra Pradesh, India
}

\author{
V. Vijaya Bhaskar* and K. Krishna Rao \\ All India Coordinated Research Project on Oil Palm, Horticultural Research Station, \\ Vijayarai - 534 475, West Godavari district, Andhra Pradesh, India \\ *Corresponding author
}

\begin{tabular}{|c|}
\hline Keywords \\
\hline $\begin{array}{l}\text { Oil palm, Bunch } \\
\text { analysis, Per cent of } \\
\text { mesocarp, \% of bunch } \\
\text { oil, } \% \text { of kernel }\end{array}$ \\
\hline Article Info \\
\hline $\begin{array}{l}\text { Accepted: } \\
18 \text { April } 2018 \\
\text { Available Online: } \\
10 \text { May } 2018\end{array}$ \\
\hline
\end{tabular}

A B S T R A C T

The present study comprising of eleven hybrid cross combinations of oil palm was carried out at Horticultural Research Station, Vijayarai, West Godavari district of Andhra Pradesh to evaluate bunch quality of oil palm hybrid cross combinations under Krishna-Godavari zone of Andhra Pradesh. The eleven tenera hybrid cross combinations of oil palm used were 128D x 291P, 124D x 266P, 18D x 32P, 35D x 291P, 65D x 111P, 104D x 98P, 82D x 266P, 109D x 291P, 115D x 291P, 148D x 98P and 220D x 98P and planted at a spacing of $9 \mathrm{~m} \mathrm{x} 9 \mathrm{~m}$ in square system of planting in a randomized block design and replicated thrice under supplemented tube well irrigation. Bunch analysis has revealed that hybrid cross combination 115D x 291P has recorded significantly highest bunch weight $(26.0 \mathrm{~kg})$, fruit weight per bunch $(16.0 \mathrm{~kg})$, per cent of fruit weight to bunch $(76.0 \%)$, per cent of moisture content of the fruit $(58.7 \%)$, per cent of oil from wet mesocarp $(53.08 \%)$ and per cent of oil from bunch (24.87\%) coupled with significantly highest number of bunches per palm per year (8.5) and yield of fresh fruit bunches (26.5 t/ha). Based on the data analysis of yield and bunch quality parameters of different dura x pisifera cross combinations it could be concluded that 115D x 291P followed by 109D x 291P have been identified as precocious in bearing coupled with fresh fruit bunch yield and bearing good quality parameters.

\section{Introduction}

Oil palm ((Elaeis guineensis) is one of the most important plantation crops grown in the coastal humid tropics of Peninsular India. In Andhra Pradesh, oil palm was introduced as a plantation crop in the West Godavari district of Andhra Pradesh during the year 1987-88. At present, the crop is under cultivation in an area of about 1,50,000 hectares mainly concentrated in the Godavari districts of Coastal Andhra Pradesh. The crop is mainly grown for the production of edible oil obtained from mesocarp of the fruit. Growers of the region are importing plant material of oil palm as the crop is an introduced one to the region. Indigenously developed and tested planting material under local climatic conditions for its growth, yield and quality characters is unavailable. Keeping in view, the rising demand for best yielding (both for fresh fruit bunches and oil recovery) and quality planting material, the ICAR-Indian Institute of Oil Palm Research, Pedavegi has started 
developing tenera seedling material (a cross between dura x pisifera as female and male parents respectively), by involving different dura $\mathrm{x}$ pisifera combinations to suit to the local conditions of peninsular India. Thus, the tenera seed material developed at ICARIndian Institute of Oil Palm Research, Subcentre at Palode, Kerala has been used to plant at Horticultural Research Station, Vijayarai with the main objective of testing their feasibility for growth and development in the region and analysis of fresh fruit bunches to identify the best fresh fruit bunch yielding tenera plant material coupled with good recovery of edible oil on per cent basis.

\section{Materials and Methods}

The present investigation on analysis of oil palm bunch was done in the hybrid cross combinations of oil palm, aged about 15 years under All India Coordinated Research Project on Oil Palm at Horticultural Research Station, Vijayarai, West Godavari district of Andhra Pradesh during the year 2007-08. Soils of the region are known as alfisols. The oil palm hybrid cross combinations developed indigenously at the ICAR-IIOPR Research Sub-centre at Palode were used in the present study and the eleven hybrid cross combinations included were 128D x 291P, 124D x 266P, 18D x 32P, 35D x 291P, 65D x 111P, 104D x 98P, 82D x 266P, 109D x 291P, 115D x 291P, 148D x 98P and 220D x 98P. Planting was done in the year 1992 with a spacing of about $9 \mathrm{~m} \times 9 \mathrm{~m}$ in square system of planting in a randomized block design with three replications. Each hybrid cross combination treatment had 8 seedlings excluding the border row. Standard package of practices (Varghese and Cecil, 1992) with regard to nutrient and irrigation management were followed during the course of investigation. Individual fresh fruit bunches of uniform maturity were used for the analysis of bunch components in the laboratory to determine the quality of oil palm fresh fruit bunches. The fresh fruit bunch component analysis was carried out at the ICAR-IIOPR laboratory located at Pedavegi, Andhra Pradesh. The bunch analysis was done as per the technique developed by Blaak et al., (1963). The data arrived was subjected to statistical analysis as per the procedure outlined by Panse and Sukhatme (1985) for interpreting the results. Critical difference was used to find out the significance among different hybrid cross combination treatments.

\section{Results and Discussion}

The data pertaining to physical components of fresh fruit bunch analysis of oil palm hybrid cross combinations is presented in Table 1 . The data were found significant for all the characters evaluated for the fresh fruit bunch quality. Among the hybrid cross combinations of oil palm, 115D x 291P has recorded significantly highest fresh fruit bunch weight $(26.0 \mathrm{~kg})$, whereas, 82D x 266P has recorded significantly lowest fresh fruit bunch weight $(7.9 \mathrm{~kg})$. Significantly highest fresh fruit weight per bunch was observed in hybrid cross combination 115D x 291P (16.0 kg), whereas, $82 \mathrm{D} \times 266 \mathrm{P}$ and $220 \mathrm{D} \times 98 \mathrm{P}$ have recorded significantly lowest fresh fruit weight $(5.5 \mathrm{~kg})$ per bunch. Significantly highest per cent of fruit weight to the bunch (76.0\%) was recorded with $115 \mathrm{D} \times 291 \mathrm{P}$ and was found at par with $148 \mathrm{D} \times 98 \mathrm{P}$, whereas, 220D x 98P has recorded significantly lowest $(53.0 \%)$ per cent of fruit weight to the bunch. Significantly highest per cent of sterile fruit per bunch was observed with 65D x 111P $(24.74 \%)$ and was found at par with the hybrid cross combination 148D x 98P (24.12\%). Significantly lowest per cent of shell per fruit was observed with 124D x 266P (4.4\%), whereas, significantly highest per cent of shell per fruit $(33.8 \%)$ was recorded with $148 \mathrm{D} x$ 98P. Significantly lowest per cent of kernel per fruit $(5.4 \%)$ was observed with 109D x 
291P and was found at par with 148D x 98P, whereas, significantly highest per cent of kernel per fruit $(10.4 \%)$ was observed with $220 \mathrm{D} x$ 98P. Based on the physical components analysis of bunch cross combination 115D x 291P has recorded significantly best results for highest bunch weight, fruit weight per bunch, per cent of fruit weight per bunch and lowest per cent of sterile fruit per bunch, lowest per cent of kernel per fruit.

The data pertaining to oil components of fresh fruit bunch analysis of oil palm hybrid cross combinations is presented in Table 2 . The data were found significant for all the characters evaluated for the fresh fruit bunch quality of oil palm. Significantly highest per cent of mesocarp per fruit $(78.0 \%)$ was observed with $18 \mathrm{D} \times 32 \mathrm{P}$ and was found at par with $65 \mathrm{D} \times$ 111P, 82D x 266P, 109D x 291P, 35D x 291P and $128 \mathrm{D} \times 291 \mathrm{P}$, whereas, significantly lowest per cent of mesocarp per fruit (49.0\%) was observed with 124D x 291P and was found at par with $148 \mathrm{D} \times 98 \mathrm{P}$. Among the hybrid cross combinations of oil palm, significantly highest per cent of moisture content of mesocarp (51.9\%) was observed with 104D x 98P which was found at par with 82D x 266P, whereas, significantly lowest per cent moisture content of mesocarp (16.2\%) was observed with 220D x 98P. Significantly highest per cent moisture content of nut $(58.7 \%)$ was observed with $115 \mathrm{D} \times 291 \mathrm{P}$, whereas, significantly lowest per cent moisture content of nut $(10.3 \%)$ was observed with 148D x 98P. Significantly highest per cent of oil from dry mesocarp (71.50\%) was recorded with $65 \mathrm{D} \times 111 \mathrm{P}$ and was found at par with many cross combinations, whereas, significantly lowest per cent of oil from dry mesocarp (62.69\%) was observed with 109D x 291P. Significantly highest per cent of oil from wet mesocarp (59.19\%) was observed with 220D x 98P followed by 115D x 291P (53.08\%), whereas, significantly lowest per cent of oil from wet mesocarp (32.97\%) was observed with 104D x 98P and was found at par with 82D x 266P. Significantly highest per cent of oil per bunch (24.87\%) was observed with $115 \mathrm{D}$ x 291P and was found at par with 109D x 291P and 65D x 111P, whereas, significantly lowest per cent of oil per bunch (14.04\%) was observed with 104D x 98P and was found at par with 124D x 266P. Based on the analysis of oil components in the fresh fruit bunch significantly lowest sterile fruit per bunch, lowest per cent of shell per fruit, lowest per cent of kernel per fruit were observed. Further, oil estimation analysis has revealed significantly moderated per cent of mesocarp per fruit, per cent of moisture content of mesocarp, per cent of oil from dry mesocarp, whereas significantly highest per cent of moisture content of nut, per cent of oil per wet mesocarp and per cent of oil per bunch were recorded by 115D x 291P.

The data pertaining to fresh fruit bunch yield components of oil palm (Table 3) was found significant for the number of fresh fruit bunches per palm per year and the fresh fruit bunch yield. Data with regard to number of leaves produced per plant was found nonsignificant among the cross combinations. However, the cross combination 115D x 291P has produced highest number of leaves (38.1 leaves per plant per annum) followed by 65D $\mathrm{x}$ 111P (37.8 leaves per plant per annum). In any plant, development of foliage is considered to be the critical aspect of plant growth. Hsiao et al., (1985) reported that attributes of leaf growth is very important for proper development and production of the economic yields. In the current study, it was noticed that production of leaves was found non-significant with different cross combinations. Gawankar et al., (2003) in oil palm have recorded similar kind of observations earlier which were in accordance to the present investigation while working with irrigation levels in oil palm. 
Table.1 Physical components in the bunch analysis of hybrid cross combinations of oil palm

\begin{tabular}{|c|c|c|c|c|c|c|}
\hline $\begin{array}{l}\text { Hybrid/Cross } \\
\text { combination }\end{array}$ & $\begin{array}{c}\text { Bunch } \\
\text { weight } \\
\text { (kg) }\end{array}$ & $\begin{array}{c}\text { Fruit } \\
\text { weight per } \\
\text { bunch (kg) }\end{array}$ & $\begin{array}{c}\% \text { of Fruit } \\
\text { weight / } \\
\text { bunch }\end{array}$ & $\begin{array}{c}\% \text { of } \\
\text { Sterile fruit } \\
\text { /bunch }\end{array}$ & $\begin{array}{l}\% \text { of } \\
\text { Shell/ } \\
\text { fruit }\end{array}$ & $\begin{array}{c}\% \text { of } \\
\text { Kernel/ } \\
\text { fruit }\end{array}$ \\
\hline $128 D \times 291 P$ & 20.7 & 14.2 & 69.0 & 18.82 & 06.0 & 6.8 \\
\hline $124 D \times 266 P$ & 22.6 & 14.7 & 65.0 & 13.19 & 04.4 & 8.8 \\
\hline $18 D \times 32 P$ & 17.5 & 13.0 & 61.0 & 18.05 & 07.8 & 6.6 \\
\hline 35D x 291P & 11.5 & 07.6 & 65.0 & 10.06 & 06.0 & 6.8 \\
\hline 65D x 111P & 12.4 & 07.8 & 62.0 & 24.74 & 06.0 & 8.4 \\
\hline $104 D$ x 98P & 14.3 & 09.5 & 67.0 & 18.20 & 12.6 & 8.6 \\
\hline $82 D$ x 266P & 07.9 & 05.5 & 69.0 & 21.74 & 06.2 & 7.2 \\
\hline 109D x 291P & 19.2 & 12.7 & 66.0 & 18.52 & 06.0 & 5.4 \\
\hline $115 D \times 291 P$ & 26.0 & 16.0 & 76.0 & 20.98 & 07.0 & 6.8 \\
\hline 148D x 98P & 11.6 & 08.7 & 74.0 & 24.12 & 33.8 & 5.6 \\
\hline $220 \mathrm{D} \times 98 \mathrm{P}$ & 10.4 & 05.5 & 53.0 & 18.37 & 06.6 & 10.4 \\
\hline Mean & 15.83 & 10.47 & 66.09 & 18.80 & 9.31 & 7.40 \\
\hline $\mathrm{SEm} \pm$ & 0.527 & 0.400 & 2.161 & 0.998 & 0.467 & 0.335 \\
\hline CD (0.05) & 1.556 & 1.181 & 6.377 & 2.943 & 1.378 & 0.988 \\
\hline
\end{tabular}

Table.2 Oil estimation in the bunch analysis of hybrid cross combinations of oil palm

\begin{tabular}{|l|l|c|c|c|c|c|}
\hline $\begin{array}{l}\text { Hybrid/Cross } \\
\text { combination }\end{array}$ & $\begin{array}{c}\text { \% of } \\
\text { Mesocarp } \\
\text { / fruit }\end{array}$ & $\begin{array}{c}\text { \% of } \\
\text { Moisture } \\
\text { content of } \\
\text { mesocarp }\end{array}$ & $\begin{array}{c}\text { \% of } \\
\text { Moisture } \\
\text { content of } \\
\text { nut }\end{array}$ & $\begin{array}{c}\text { \% of oil / } \\
\text { dry } \\
\text { mesocarp }\end{array}$ & $\begin{array}{c}\text { \% of oil / } \\
\text { wet } \\
\text { mesocarp }\end{array}$ & $\begin{array}{c}\text { \% of oil } \\
\text { / bunch }\end{array}$ \\
\hline 128D x 291P & 73.00 & 38.5 & 47.0 & 69.50 & 44.12 & 22.23 \\
\hline 124D x 266P & 49.00 & 34.7 & 28.2 & 71.25 & 46.51 & 14.79 \\
\hline 18D x 32P & 78.00 & 40.1 & 28.4 & 67.90 & 40.61 & 19.65 \\
\hline 35D x 291P & 73.00 & 46.1 & 52.5 & 69.84 & 37.68 & 18.13 \\
\hline 65D x 111P & 75.40 & 31.6 & 39.0 & 71.50 & 48.85 & 22.78 \\
\hline 104D x 98P & 65.00 & 51.9 & 33.3 & 68.89 & 32.97 & 14.04 \\
\hline 82D x 266P & 75.00 & 48.1 & 41.3 & 69.31 & 36.37 & 18.61 \\
\hline 109D x 291P & 73.40 & 26.4 & 49.9 & 62.69 & 46.12 & 22.46 \\
\hline 115D x 291P & 63.00 & 22.8 & 58.7 & 68.71 & 53.08 & 24.87 \\
\hline 148D x 98P & 50.00 & 33.0 & 10.3 & 70.71 & 47.47 & 18.09 \\
\hline 220D x 98P & 62.00 & 16.2 & 36.7 & 70.65 & 59.19 & 19.40 \\
\hline & & & & & & \\
\hline Mean & $\mathbf{6 6 . 9 8}$ & $\mathbf{3 5 . 4 0}$ & $\mathbf{3 8 . 6 6}$ & $\mathbf{6 9 . 1 8}$ & $\mathbf{4 4 . 8 2}$ & $\mathbf{1 9 . 5 5}$ \\
\hline SEm \pm & 1.798 & 1.520 & 1.282 & 1.510 & 1.436 & 0.855 \\
\hline CD (0.05) & 5.303 & 4.483 & 3.780 & 4.454 & 4.237 & 2.521 \\
\hline
\end{tabular}


Table.3 Fresh fruit bunch yield components of hybrid cross combinations of oil palm

\begin{tabular}{|l|c|c|c|c|}
\hline $\begin{array}{l}\text { Hybrid/Cross } \\
\text { combination }\end{array}$ & $\begin{array}{c}\text { No. of leaves/ } \\
\text { palm/year }\end{array}$ & $\begin{array}{c}\text { No. of bunches/ } \\
\text { palm/year }\end{array}$ & $\begin{array}{c}\text { Bunch weight } \\
\text { (kg) }\end{array}$ & Yield (t/ha) \\
\hline 128D x 291P & 36.0 & 5.2 & 21.6 & 16.1 \\
\hline 124D x 266P & 36.6 & 5.7 & 22.7 & 18.4 \\
\hline 18D x 32P & 37.1 & 5.0 & 19.5 & 13.8 \\
\hline 35D x 291P & 34.4 & 4. & 21.4 & 13.0 \\
\hline 65D x 111P & 37.8 & 3.1 & 20.2 & 8.9 \\
\hline 104D x 98P & 35.1 & 5.1 & 22.0 & 16.0 \\
\hline 82D x 266P & 34.1 & 6.3 & 19.1 & 17.2 \\
\hline 109D x 291P & 37.6 & 5.6 & 21.4 & 17.1 \\
\hline 115D x 291P & 38.1 & 8.5 & 21.8 & 26.5 \\
\hline 148D x 98P & 37.5 & 6.9 & 19.7 & 19.4 \\
\hline 220D x 98P & 36.1 & 5.0 & 19.8 & 14.1 \\
\hline & & & & \\
\hline Mean & $\mathbf{3 6 . 4}$ & $\mathbf{5 . 5}$ & $\mathbf{2 0 . 1}$ & $\mathbf{1 6 . 4}$ \\
\hline SEm \pm & 1.32 & 0.44 & 1.21 & 1.12 \\
\hline CD $(0.05)$ & $\mathrm{NS}$ & 1.30 & NS & 3.30 \\
\hline
\end{tabular}

Significantly highest number of fresh fruit bunches per palm was observed with $115 \mathrm{D} x$ 291P (8.5), whereas, 65D $\mathrm{x} 111 \mathrm{P}$ has recorded significantly lowest number of fresh fruit bunches (3.1) produced per palm per year. The fresh fruit bunch weight was found non-significant for the hybrid cross combinations of oil palm. However, 124D x $266 \mathrm{P}$ has recorded highest fresh fruit bunch weight $(22.7 \mathrm{~kg})$ followed by $115 \mathrm{D}$ x $291 \mathrm{P}$ $(21.8 \mathrm{~kg})$, whereas, cross combination $82 \mathrm{D} \mathrm{x}$ $266 \mathrm{P}$ has recorded significantly lowest fresh fruit bunch weight $(19.1 \mathrm{~kg})$. The data pertaining to fresh fruit bunch yield was found significant during the study with different cross combinations of oil palm. Hybrid cross combination 115D x 291P has recorded significantly highest fresh fruit bunch weight (26.5 t/ha), whereas, 65D x $111 \mathrm{P}$ has recorded significantly lowest (8.9 $\mathrm{t} / \mathrm{ha}$ ) fresh fruit bunch yield. Variation in the yield components of oil palm certainly might be due to the inherent genetic nature of the cross combinations under a fixed set of environmental conditions. In oil palm, the number of fresh fruit bunches produced is dependent on the number of productive female inflorescences produced on the palm. Cross combinations evaluated under similar set of environmental conditions with application of same dose of nutrients and irrigation water to all the palms recorded a variation which might be due to the inherent genetic makeup of the palms. However, ability of the cross combinations to exert more water and nutrients from the soil is the most important heritable character which was observed with 291P, which has recorded several positive parameters with regard to growth and development of hybrid cross combinations. Murugesan and Shareef (2014) have expressed similar kind of opinion while working on the development of inter-specific hybrids for dwarfness in American oil palm.

Based on the analysis of physical components of fresh fruit bunches, the cross combination $115 \mathrm{D} \times 291 \mathrm{P}$ has recorded significantly best results with regard to highest bunch weight, fruit weight per bunch, per cent of fruit 
weight per bunch and lowest per cent of sterile fruits per bunch and lowest per cent of shell and kernel per fruit. Analysis of oil in the fresh fruit has revealed that 115D x 291P recorded moderate in the per cent of mesocarp per fruit, per cent of moisture content of mesocarp, per cent of oil from dry mesocap, whereas, significantly highest per cent of moisture content of nut, per cent of oil per wet mesocarp and per cent of oil per bunch were recorded. Further, it may be concluded that 291P pisifera male parent with different dura female parents has contributed a consistent and significantly best quality aspects when compared with other pisifera male parents. Hence, 291P pisifera male parent can be recommended to use as the best male parent in the production of indigenous tenera hybrid cross combinations suitable to the Indian sub-continent climatic conditions.

\section{References}

Blaak, G., Sparmaaij, L.D. and Menendez, T. 1963. Breeding and inheritance in the oil palm (Elaesis guineensis Jacq.). II. Methods of bunch quality analysis. Journal of West African Institute of Oil Palm Research. 4: 146-155.
Gawankar, M.S., Devmore, J.P., Jamadagni, B.M., Sagvekar, V.V and Hameedkhan, H. 2003. Effect of water stress on growth and yield of tenera oil palm. Journal of Applied Horticulture. 5(1): 39-40.

Hsiao, T.C., Silk, W.K and Jing, J. 1985. Leaf growth and water deficits. Biophysical effect. In: Control of leaf growth. Baker, N.R. W.J. Davies and C.K. Ong (Eds.) Cambridge University Press, Cambridge. 239-666.

Murugesan, P. And Shareef, M. 2014. Yield, bunch quality and vegetative traits of American oil palm (Elaeis oleifera, $\mathrm{HBK})$ population in India. Indian Journal of Horticulture. 71(1): 23-27.

Panse, V.G. and Sukhtame, P.V. 1985. Statistical methods for agricultural workers. Indian Council of Agricultural Research, New Delhi.

Varghese, P.T. and Cecil, S.R. 1992. Oil palm management. pp. 33-48. In: Oil palm production technology. (Eds.) Nair, M.K. and Nampoothri, K.U.K Central Plantation Crops Research Institute, Kasargod, India.

\section{How to cite this article:}

Vijaya Bhaskar, V. and Krishna Rao, K. 2018. Analysis of Bunch Quality in Oil Palm Hybrid Cross Combinations under Krishna-Godavari Zone of Andhra Pradesh, India. Int.J.Curr.Microbiol.App.Sci. 7(05): 2488-2493. doi: https://doi.org/10.20546/ijcmas.2018.705.286 